\title{
DIE STRYD RONDOM DIE LEER AANGAANDE DIE TRINITEIT MET BESONDERE VERWYSING NA DIE VIERDE EN
}

\section{TWINTIGSTE EEUE}

\section{Inleiding}

1. Wie oor die Wese van God spreek staan op heilige grond. Sou ons dan nie liewer volstrek swyg as dit gaan oor die wese van die Drie-eenheid in plaas van ons te besondig aan Hom, die Oneindige wat hoër is as alle verstand? Maar die weg van absolute swye is ewe sondig as die van roekelose en oneerbiedige spreke. Wie spreek waar swye gebiedend is, sondig; maar wie swyg waar spreek die eis is, sondig eweseer. ${ }^{1}$

Die enigste kenbron is die Woord van God: Sola Scriptura. In sy Institusie kom die volgende woorde van Calvyn i.v.m. die Triniteitsleer na vore: „Die foutlose maat, beide van dink en spreek, moet van die Skrif afkomstig wees". ${ }^{2}$ "Oor die verborgenhede van die Skrif moet met groot ingetoënheid gespreek word sodat ons nie verder gaan as wat die Heilige Skrif bied nie. Laat ons aan God die kennis van Homself oorlaat, want $\mathrm{Hy}$ is ' $\mathrm{n}$ voldoende getuie vir Homself. En dit sal ons doen as ons Hom so bely soos Hy Hom aan ons in sy Woord geopenbaar het. Ons moet na Hom soek soos Hy in sy Woord spreek en niks anders oor Hom spreek as wat uit die Woord geneem is nie". ${ }^{3}$ In hierdie uitspraak neem Calvyn die uitspraak van Chrysosthomos ter harte.

2. Die noodsaak van dogmatiese formulering. Die vraag is, waarom nie maar volstaan by die eenvoudige Bybelse Trinitariese doopbevel: „En doop hulle in die Naam van die Vader en die Seun en die Heilige Gees"? (Matt. 28 : 19), of by die eenvoudige Trinitariese seënbede en belydenis nie?

Die antwoord is: Luther en Calvyn sou dit graag wou doen. Luther sê bv. dat hy sou liefs wou bly staan het by die eenvoudige belydenis: „Ek glo in God die Vader en in die Seun en in die Heilige Gees"."

Dit was alreeds die standpunt van Irenaeus en biskop Alexander vóór die Ariaanse stryd, naamlik dat die geheimenis van die bestaan en uitgaan van die Seun selfs vir die Evangeliste en engele 'n onuitspreeklike geheimenis was. Alexander wou liewer maar die volle Godheid van Jesus Christus bely asook die hipostatiese onderskeidenheid (d.w.s. die persoonlikheid) van die Vader en die Seun. ${ }^{\circ}$

Ook Calvyn wil liewer maar al die terme begrawe sien, indien maar net die geloof sou vasstaan „dat die Vader, Seun en Heilige Gees één God is en dat die Seun nie die Vader is nie en die Heilige Gees ook nie die Seun en die Vader nie, maar dat hulle (die Drie Persone dus) deur ' $n$ besondere eienskap van mekaar onderskei is. ${ }^{\circ}$

So sou van die hedendaagse teoloë liewer wou bly by die eenvoudige belydenis: Ek glo in God, die Vader en in Jesus Christus, 
sy Seun en in die Heilige Gees" en by die seënbede van die apostel: „Die genade van ons Here Jesus Christus, die liefde van God en die gemeenskap van die Heilige Gees sy met julle almal" (2 Kor. $13: 13)$. $^{7}$

Maar die kerk word deur die dwaalleer gedwing om sy belydenis te formuleer. Calvyn het in sy botsing met Gentilis, ${ }^{8}$ Servet en die Sociane gesê dat hy teen wysneusig uitgedinkte terme is wat met bygelowigheid verdedig word en wat meer tot twis as tot stigting dien en wat die mense aftrek van die eenvoudigheid van die Woord van God.

Teen die beswaar dat terme soos „Persoon" en „Drie-eenheid” gebruik word omdat dit nie woorde is wat in die Skrif voorkom nie, antwoord Calvyn: die kerk was deur die grootste noodsaaklikheid gedwing om die woorde Drie-eenheid, Persoon ens. te gebruik om die dinge in die Skrif wat vir ons begrip ingewikkeld is, in duideliker woorde uit te lê, woorde wat getrou die waarheid van die Heilige Skrif dien. ${ }^{\ominus}$

Die groot voordeel van die oud-kerklike terme is dat dit die waarheid teen dwaalleraars en lasteraars verdedig en tog niks by die Skrif byvoeg nie.

Arius (sê Calvyn) sê wel dat Christus God is. Arius sê ook: Christus is een met die Vader. Maar (sê Calvyn) hieragter lê tog venyn verborge. Sê bietjie vir Arius hy moet sê: eenswesens met die Vader (homo-ousios), dan ruk jy Arius se masker af. ${ }^{10}$ Arius sal nie eenswesens wil sề nie, want dan sal hy sy verborge subordinatianisme en adoptianisme moet loën. En tog, as ons ,eenswesens” sê, dan het ons niks by die Skrif bygevoeg nie.11

Sê weer aan Sabellius dat in een wese van God 'n drie-eenheid van persone is, dan ontmasker u Sabellius. ${ }^{12}$

Daarom konkludeer Calvyn, alhoewel hy sou verkies om te volstaan met die Trinitariese doopbevel of by die eenvoudige Trinitariese seënbede, dat dit beter is om die dwaalleer „,deur ons woorde uit te lok om hulleself te openbaar as om ter wille van hulle op 'n duister manier te spreek". ${ }^{13}$ Calvyn sê met die oudkerklike terme (nl. Triniteit, Eenswesens, Persone), "sê ons in een woord wat die Skrif sê en het ons die ydele gepraat stopgesit". ${ }^{14}$

Ons beweer allermins dat die terme soos Drie-eenheid, Wese, Persone, wat in die Skrif self nie gevind word nie, volmaak sou wees. Hulle is as terme gebrekkig-menslik en inderdaad niks meer as behulpsels. Dog die geskiedenis het geleer: hulle bewys hulle diens in die afwys van die leuen, omdat hulle heenwys na die saak waarom dit in die Bybel gaan. Of beter gesê: hulle inhoud is in die Openbaring gegrond. Daarom handhaaf ons sonder enige voorbehoud die uitspraak van prof. Bavinck: ,Met die belydenis van Gods Drieeenheid staan en val die ganse Christendom, die gehele besondere openbaring. Dis die kern van die Christelike geloof, die wortel van alle dogma, die substansie van die nuwe verbond". ${ }^{15}$

3. 'n Kern leerstuk. Die stryd rondom die Drie-eenheid spits hom veral toe op die vraag of Christus waaragtig God is. Die vraag na 
die Christus: „Wie sê die mense is Ek?" (Matt. $16: 13$ ), is die kernvraag in die belydenis van die kerk. Die eerste 8 eeue is in beslag geneem deur christologiese twiste.10

Telkens in die dogmageskiedenis van Montanus tot by Hegel, ${ }^{17}$ maar ons kan die lyn deurtrek na die $20 \mathrm{e}$ eeu, is die mening gehuldig dat die Drie Persone is drie opeenvolgende periodes in die kerkgeskiedenis. In sy kritiek hierop sê Bavinck, word die wese van God neergetrek in die stroom van die wording, van evolusie. Dit was juis die stryd van die Patres om in die Christelike teologie hierdie paganistiese, panteïstiese element uit te ban; om God los te maak uit die evolusie van die wording; om die Triniteit op te vat as 'n ewige lewensbeweging in die Goddelike wese self. Alle werke na buite is werke van die ganse Triniteit.

Meer as enige ander dogma is die dogma oor die Triniteit 'n misterie wat natuur en rede ver te bowe gaan en alleen uit die besondere openbaring geken kan word. Augustinus verklaar onomwonde dat die Triniteit nie deur die rede kenbaar is nie.

Die leer oor die Triniteit is die antwoord teen deïsme (wat 'n kloof lê tussen God en sy skepsel); teen panteïsme (wat die grens uitwis tussen Skepper en skepsel), teen die monisme (van die Jode), teen die politeisme (van die heidene), ${ }^{18}$ en teen die sinkretisme.

Die belydenis oor die Drie-eenheid is die kernleerstuk; hiermee staan en val die Christendom; dis die wortel van alle dogma; dis die hart van die Christendom. In elke Christelike belydenis en dogmatiek is die diepste vraag hierdie vraag: hoe God Eén en tog Drievoudig kan wees?! In die Triniteit klop die hart van heel die openbaring Gods tot verlossing van die mensheid. Alle heil en seën kom ons uit God Drie-enig toe. In die Naam word ons gedoop; die Naam is die hoofsom van ons belydenis; van die Naam daal alle seën op ons neer; aan die Naam bring ons ewig dank en ere; in die Naam vind ons harterus en vrede vir ons gewete. Aan die leer van die Triniteit is die saligheid in hierdie en die toekomende lewe verbonde. ${ }^{19}$

\section{Agtergrond van die stryd van die $4 \mathrm{e}$ eeu}

Die stryd van die 4e eeu rondom die leer aangaande die Drie-eenheid het sy wortels ver terug. Dit was die kulminasie van verskeie gedagtestrominge wat sy beslag gekry het in die vierde eeu. Dis 'n studie op sigself om al die invloede uit die vorige eeue aan te dui. Vir die doeleindes van hierdie werkstuk dui ons net kortliks die kerngedagtes van enkele strominge ten tye van die ou kerk aan:

1. Die Platoniese idee-leer.

2. Die Gnostiek.

3. Die Monargisme.

1. Platoniese idee-leer. Plato was 'n Griekse wysgeer (427-347 v.C.) in Athene. Hy was 'n leerling van Socrates. Beroemd is sy "Akademie" wat van 387 v.C. tot 529 n.C. bestaan het. ${ }^{20}$ Die invloed van Plato op die denke van sy tyd en vir eeue daarna is onberekenbaar. Sy denke 
het heel die Europese geesteslewe beheers, al is dit spoedig met vreemde elemente vermeng.

Die verhouding van God tot hierdie wêreld is deur Plato ondersoek. Hy gaan uit van ideё (wat eintlik niks anders as algemene begrippe is) wat hy dan verhef tot algemene begrippe (metafisiese principia), tot 'n soort tussenwesens waarmee die Demiurg ('n laere God) die kosmos gevorm het. Hoewel Aristoteles hierdie ideëleer aan 'n skerp kritiek onderwerp het, het die gedagte dat aan alle dinge 'n geestelike prinsipe ten grondslag lê sy beslag gekry in die Griekse filosofie. Veral die Stoa het sterk nadruk gelê op die ideëleer. Hulle noem dit die logos spermatikos waaruit alle lewe ontkiem.

Maar dit was veral Philo (50 n.C.) wat al die verskillende elemente: Platoniese ideëleer, Stoïcynse logosleer en Ou-Testamentiese wysheidsleer tot 'n stelsel versmelt het. Hy gaan daarby uit van die dualisme tussen God en wêreld. God is die onbeskryfbare - ons kan slegs sê dat $\mathrm{Hy}$ is, nie wat en wie $\mathrm{Hy}$ is. Daarom kan Hy ook nie in onmiddellike aanraking met die materie staan nie. God maak dan van "logoi", ideë, gebruik as tussenskakels waarmee Hy dan in verbinding tree met hierdie wêreld.

Hierdie "logoi", middelaars, is velerlei en bevind hulle in die Goddelike denke. Hierdie logos wat nou een met God is en dan weer van God onderskeie is, staan as ' $t$ ware tussen God en die wêreld en het aan beide deel; hy is nie ongeskape soos God en tog ook nie geskape soos die eindige dinge nie; hy is plaasvervanger, gesant, tolk, skadu Gods, ja sy eersgebore Seun, sy oudste seun in onderskeiding van die wêreld wat sy jongste seun is.

Philo noem hierdie logos selfs God, maar dan ,deuteros Theos". $\mathrm{Hy}$ is ' $\mathrm{n}$ dubbel- en tussenwese, een eienskap met God en tog 'n persoon, nóg identies met God, nóg 'n skepsel soos die wêreld, heen en weer swewend tussen 'n onpersoonlike eienskap en 'n persoonlike selfstandigheid, maar daarom juis geskik geag as middelaar tussen God en die wêreld. As volkome transendent kan God nie onmiddellik met die skepsele in verbinding tree nie. Hy het daartoe allerlei tussenwesens nodig. Die leer van die tussenwesens is by Philo gebore uit die platoniese teenstelling tussen God en die wêreld.

Hierdie tussenwesens is nóg God nóg skepsel, nóg persoon nóg eienskap; het deel aan beide, wis die grenslyn uit wat in die $\mathrm{Ou}$ Testament altyd die skepsel van die Skepper skei en onderskei.

So berei hierdie stelsel die filosofie van die Gnostiek en Kaballa voor.

Hierdie tussenwesens by Philo het geen soteriologiese betekenis nie. Hulle dien net as "ligvonke" en tot mededeling van kennis, stel net die voorbeeld, maar van 'n verband tussen die tussenwesens en die Messias is geen sprake. Vir Philo is die menswording van die logos 'n ongerymde gedagte. In die Nuwe Testament is hierdie juis die hoogste openbaring. Hierdie tussenwesens neem hoe langer hoe meer toe deur emanasie. Hulle bring geen gemeenskap tussen God en wêreld tot stand nie. ${ }^{21}$ Die kosmologiese dualisme bring by Philo 'n etiese dualisme mee wat uitloop op 'n deissme. 
2. Die Gnostiek. Die ou Christelike Kerk het te doen gehad met die geweldige teenstand van die Heidense kultuur. Aanvanklik het die heidense magte deur vervolging, haat en spot die Christelike geloof bedreig. Maar langsamerhand moes die heidense wêreld met die Christendom rekening hou en dit wetenskaplik aanval. Die vernaamste wetenskaplike bestryders was Celsus, Porphysius, Tronto en Julianus. Al die argumente wat latere eeue teen die Christendom ingebring is, is reeds by hulle te vinde.

Tog het ook hierdie wetenskaplike bestryding die Christendom nie oorwin nie. Die heidendom het nou voor die alternatief gestaan om of die ou heidense godsdienste tot nuwe lewe te bring (soos die Neopythagoreïsme en Neoplatonisme, en verskillende van die misteriegodsdienste, veral die Mithraskultus), of om die Christendom met die Heidendom te vermeng en te verbind soos dit geskied het in die Gnostisisme en Manichiisme. Veral die Gnostiek was 'n magtige poging om die Christendom in die kombinasie ${ }^{22}$ van allerlei heidense elemente, neo-platoniese wysbegeerte, Siriese en Fenisiese mitologie, Chaldese astrologie, Persiese dualisme ens. op te neem, en so van sy absolute karakter te ontdoen. ${ }^{23}$ Gedurende die tweede eeu bereik die Gnostiek sy hoogtepunt, veral in die Manicheisme (as sg. Christelike gnostiek teenoor kaballa as vorm van Joodse gnostiek).

Die hoofvraag van die Gnostiek is hoe die menslike gees in die bande van die materie gekom het en daaruit weer bevry kon word. Gewoonlik is God in die Gnostisisme die abstrakte, onderskeidlose eenheid. Uit Hom is die materie, die oorsaak van die kwaad, nie te verklaar nie. Dié word afgelei uit 'n laere God, 'n Demiurg, wat tussen die hoogste God en die sinlike wêreld in staan en vereenselwig word met die God van die Ou Testament.

Ter verlossing van die geeste wat geboei sit in die materie, gaan daar verskillende "aeone" uit God uit. Christus is dan so 'n Aeoon, 'n ,ligvonk" wat uit die goddelike pleroma neerdaal na hierdie donker wêreld om weer as voorbeeld, die pad aan te dui na die goddelike pleroma. ${ }^{24}$ Christus word doceties opgevat, nl. dat Hy 'n skynliggaam aangeneem het. Die Gnostiek loën die daadwerklikheid en noodsaaklikheid van Christus se versoeningswerk. Die hoogste saligheid bestaan in kennis (gnosis). Kennis met askese maak salig. Die pistis (geloof) mag wel goed wees vir die onontwikkeldes, maar die gnosis (filosofie) is die hoogste besit. Christus word prototipe van die verloste, sonder enige werklike historisiteit.

Die Christelike geloof word verander in 'n spekulatiewe filosofie wat alle eeue deur tot in die stelsels van Hegel en Schilling en tot by ons hedendaagse teoloë van die nuwere teologie sy invloed laat geld. ${ }^{25}$

By die Gnostiek wat uit en uit 'n sinkretisme is, gaan die positiewe, absolute inhoud van die Christelike religie verlore.

Dis 'n veelkoppige hydra, 'n magtige dinksisteem wat sy hoogkonjunktuur beleef in die tweede eeu n.C. Dis geen geslote sisteem met 'n dogmatiek nie. In wese 'n heidense geestesstroming wat as stelsel ontstaan het uit protes teen die Christendom.

Die basiese eienskappe kom daarop neer dat die gnosis tot inhirente eienskap in die mens verabsoluteer word. Dit lei tot 'n on- 
skriftuurlike Godsbegrip; die wêreld is voortgebring deur 'n onvolmaakte God.

3. Die Monargisme. Die jong Christelike kerk het teen magtige invloede moes standhou. Wie die geskiedenis van die vroeë kerk bestudeer kan nie anders as om met ootmoed en diepe dankbaarheid vervul te word as die duidelike leiding van Gods Gees gesien word; hoedat die kerk vasgehou is (Openb. $1: 16$ ) deur Jesus Christus; hoedat die kerk te midde van openlike aanslae van buite en subtiele verleidinge van binne stand gehou het en belydenisse formuleer het wat die toets van die Skrif en die eeue weerstaan.

Aan die begin van die $3 \mathrm{e}$ eeu is die grondslae van die Christelike teologie gelê. Die eerste periode, nl. van die $2 e$ tot die $4 \mathrm{e}$ eeu was die van dogmavorming. By die Apostoliese vaders is eintlik nog nie veel sprake van dogmavorming. Die Christendom was geen vrug van menslike ondersoek en nadenke, maar van openbaring en eis daarom in die eerste plek geloof. ${ }^{20}$

Naas die uitwendige bedreiginge het gedurende die $3 \mathrm{e}$ eeu allerlei inwendige twiste na vore getree. Die groot stryd van die 3e eeu was oor die verhouding van die Logos (en die Gees) tot die Vader, en die kettery wat bestry moes word was die Monargisme ${ }^{27}$ in sy tweërlei vorm van dinamistiese en modalistiese Monargisme.

Die Monargisme was 'n poging om die monoteïsme te beskerm, wat in gevaar gekom het deurdat Christus beskou is as ,'n God", 'n tweede God. Selfs die Apologeet Justianus Martyr noem Christus o $\vartheta \varepsilon o s \delta \varepsilon v \tau \varepsilon \rho \alpha \chi \omega \rho \alpha-$ eersgebore van die skepping. Hy sien Christus as ondergeskik aan die Vader; Hy neem die tweede plek in. ${ }^{28}$ Ook die Alexandrynse vader, Origines praat van Theos Deuteros, bedoelende die Seun van God.

Die Monargisme was dan 'n reaksie om die monoteîsme te bewaar. Tweërlei Monargisme word onderskei:

(i) Dinamistiese monargiste: Ebioniete, Theodotus van Bizanticum, Artemas, Paulus van Samosata, Arius. Hulle leer: Jesus word sy Godheid ontsê; Jesus was 'n mens, in besondere mate deur die goddelike Logos toegerus en met Gods Gees gesalf.

(ii) Modalistiese monargiste: Noëtus, Praxeas e.a. en veral Sabellius (vandaar ook genoem Sabellianisme). Hierdie leer erken die Godheid van Christus maar vereenselwig Vader en Seun en kom so tot patripassianisme ( = die Vader het gely aan die kruis).

Teen hierdie agtergrond (daar is nog meer te noem om die decor van die stryd in te klee), van aanslae van buite: Platonisme en Gnostisisme en aanslae van binne: Monargisme, wil ons dan nou die kulminasie van die stryd van die $4 \mathrm{e}$ eeu besien.

\section{Die vierde eeu}

Die stryd aangaande die leer oor die Drie-eenheid spits hom veral toe op die vraag of Christus waarlik God is. In die worsteling om tot helderheid te kom, is hoofsaaklik drie weë gevolg: ${ }^{2 \theta}$

1. Arius (Dinamistiese monargisme).

2. Sabellius (Modalistiese monargisme).

3. Eutyches (Monofisitisme). 
1. Arianisme. Die waaragtige mensheid van Jesus is ten volle erken, maar sy goddelike waardigheid is dan gesien as 'n gawe van die Vader onder Wie Hy altyd gestaan het en van Wie Hy nou (na sy volbragte heilswerk) 'n loon ontvang, nl. goddelike waardigheid onder of naas die Vader.

Hieruit spruit die visie van adoptianisme wat leer dat Jesus Christus nie die natuurlike, wesenlike Seun van God altyd was nie, maar dat Hy ná sy volbragte werk deur die Vader as Seun aangeneem is en so tot goddelike rang verhoog is, gewoonlik gesubordineer aan die Vader. ${ }^{30}$ In plaas van die natuurlike, wesenlike eenheid tussen Jesus Christus en God, sien Paulus van Samosata die eenheid as 'n eenheid van wil. Dieselfde gedagtes kry ons by Arius. Hy bely bv. dat Jesus Christus God is, maar voeg daaraan toe: Tot God gemaak deur die Vader en daarom het Hy 'n begin gehad. Jesus Christus is één met die Vader, maar $\mathrm{Hy}$ is tot één gemaak deur die Vader. ${ }^{31}$ Hierdeur ontsê hy dan in 'n sekere sin die eienskappe van ware divinitas aan Christus; verder ontsê hy ook aan Christus die ewige eer en mede-ewige majesteit.

Hierdeur (bv. dat Jesus ná sy heilswerk vergoddelik is en dat Hy nie natuurlik nie, maar eties deur die wil van God Seun geword het) is in prinsipe die weg gebaan tot die latere liberale teologie ${ }^{32}$ wat in Jesus Christus bloot ' $n$ menslike voorbeeld sien, ook voorbeeld daarvan dat die mens deur wilsgehoorsaamheid aan die Vader vergoddelik kan word. ${ }^{33}$

Hierdie gedagtestruktuur het baie modaliteite en staan bekend as die Arianisme. Arius was leerling by die eksegeteskool van Lucianus. Hy was geskool in die kritiese Bybelstudie en was in wetenskaplike sin geen sistematikus nie. Die gevolg is dat mens die gedagtes van Arius moet probeer opbou tot 'n samehangende geheel. ${ }^{34} \mathrm{Op}$ hierdie wyse is sy gedagtes as volg:

Arius se leer word beheers deur die gedagte dat God Een is. Alleen "die Vader" is die Een, Enige God en alleen Hy is gennétos (ongebore) en agenétos (ongeword).

Alle andere is gennétos en genétos (gebore en geword), d.w.s. (vir Arius) geskape en gemaak. As die Skrif dus van die Seun sê dat Hy Mongenés is (Eniggeborene), dan sê die Skrif dat hy gennétos is, gebore is en dus ' $n$ begin gehad het. God alleen is ongebore (monos agennétos), die Seun is gebore, al is dit eniggebore (monogenis). Die Seun het 'n begin gehad, God is egter sonder begin.

As die Seun ' $n$ begin gehad het, is Hy op een of ander manier gemaak, geskape al is dit uit die nie-synde. Die feit dat die Seun monogenés, enig-gebore is, gee aan Hom nog nie gelyke ewigheid met God nie, maar wil alleen sê dat Hy nie skepsel is op dieselfde wyse as die ander skepsele dit is nie, maar dat $\mathrm{Hy}$ 'n tussenwese tussen God en die geskapene is. Hy is Ktisma teleion (volmaakte skepsel) wat vóor alle andere vóór die tyd (ackronós) deur God voortgebring is (gennétos en genitos) uit die nie-synde (eks ouk onton) en deur wie alle andere skepsele gemaak is. Met betrekking tot die ander skepsele is Hy ,ewig", maar nie met betrekking tot God die Vader nie. Die Seun was nie altyd nie - Hy was nie vóór 
Hy geword het nie; die Seun is tydeloos gebore maar Hy was nie vóór sy geboorte nie.

Hiervoor beroep Arius hom breedvoerig op die Skrif. Tekste wat hy aanvoer is: Deut. $6: 4$, Spreuke $8: 22,1$ Kor. $1: 24$, Ps. 45, Matt. 12 : 28, Matt. 26 : 39, Matt. $27: 46$, Markus 13 : 32, Hand. 2 : 36 - dat God vir Jesus Christus tot Here en Christus gemaak het, terwyl Filipp. 2 : 6 v.v. laat sien dat die Vader Hom verhoog het en aan Hom 'n heerlike naam verleen.

Op grond van sy eie uitleg van hierdie en dergelike Skrifgedeeltes vind ons by Arius die volgende stellings:

(i) Die wesenlike eienskappe van God is: agennétos (ongebore), agenétos (ongeword), sonder begin, ewig. Alleen Hy wat hierdie eienskappe besit, is volmaak, is ewige waaragtige God.

(ii) Hieruit vloei voort dat alleen $\mathrm{Hy}$ wat só is (ewig, ongebore, ongeword en dus volmaak) op volle goddelike waarde en waardigheid aanspraak kan maak.

(iii) Dat die Seun achronos gennétos is (voortydelik gebore) maak nog nie dat Hy ewig is nie, want achronós en ewig is nie vir Arius dieselfde nie. Trouens bostaande Skrifgedeeltes dui vir Arius daarop dat die Seun ondergeskik is aan God, dat Hy dus nie ten volle God is nie, en dat Hy nie bogenoemde eienskappe besit nie en dus nie volkome is nie. Daarom kan gelyke eer met God waaragtig nie aan Hom toegebring word nie.

(iv) En tog is die Seun Goddelik (maar goddelik beteken nog nie God nie, net soos voor-tydelik nog nie ewig beteken nie). Hy kry hierdie eer deur die gedurige wilseenheid met God, deur sy gedurige sedelike gehoorsaamheid aan die Vader.

Die konsekwensie wat Arius hieruit mak is dat die mens hierdie doksa, hierdie heerlike eer, deur deugsame lewe verkry terwyl die mens sy oog hou op die voorbeeld van Jesus Christus wat op hierdie wyse hierdie heerlike eer ontvang het. God het aan Jesus hierdie doksa geskenk en die mens kan dit nou deur deugsaamheid erlang.

Hierdie leer vind ook sy neerslag in die leer van Pelagius wat die versoenende en plaasbekledende werk van Christus loën. Christus se versoeningsdaad was nie nodig nie, alleen in soverre Hy voorbeeld was van 'n deugsame lewe.

Hierin is duidelik die spore van die platoniese idee en die sinkretistiese Gnostiek wat die Logos net sien as die "ligvonk" wat uit die goddelike volheid (pleroma) neergedaal het om op aarde weer die pad te kom aandui terug na die godsaligheid, en dat dit te verkry is deur sedelike gehoorsaamheid.

Alexander en Athanasius. Die teenstanders van Arius het teenoor bogenoemde gedagtegang van Arius gestel dat Jesus Christus wesenlik God is. Die ,sjibbolet" is homo-ousios, eenswesens met die Vader. En indien dit só is, dan besit Hy ook al die eienskappe wat voortvloei uit die waaragtige wesenlike Godheid, nl. gelykheid, ongewordheid, mede-ewigheid en gelyke eer met die Vader.

Teenoor Arius se ontkenning stel hulle duidelik dat die Seun 
agenétos (ongeword) is. Hy is wel achronós gennétos, tydeloos (voor alle eeue) gebore uit die Vader, maar hierdie geborenheid van die Seun uit die Vader dui nie op 'n mitiese ewigheid wat die Seun se werklike en wesenlike ewigheid ontken nie, maar dui 'n verhouding tussen die Vader en die Seun aan, nl. die verhouding van die liefde. ${ }^{35}$

Alexander en Athanasius wil teenoor Arius se ontkenning van die ewigheid van die Seun deur die woorde gennétos en genétos, (ongebore en ongeword), baie duidelik die Seun se mede-ewigheid saam met die Vader vashou.

Die Seun is wesenseen met die Vader in 'n ewige ko-eksistensie met die Vader. Die genoemde Skrifgedeeltes van Arius, stel Alexander en Athanasius die regte uitleg daarvan, en dat dit veral betrekking het op die menslike natuur van Christus. Hulle verwys veral na Joh. $1: 1-3,13$ en 18; Joh. $10: 15$ en 30; Joh. $14: 8,9,10$ en 28; Matt. 3 : 17; 11 : 27; Rom. 8 : 32; Kol. 1 : 15, 16; Hebr. 1 : 2 v.v.; 1 Joh. 5 : 1; Ps. 2 : 7; Ps. 110 : 3; Ps. 35 : 10; Spreuke 8 : 10; Maleagi $3: 6 .^{30}$ Die hele Christologie van Athanasius kan eintlik saamgevat word in: homo-ousios tói Patri of tói Theói (eenswesens met die Vader of God). Homo-ousios herhaal hy meer as honderd maal in sy geskrifte. ${ }^{37}$

Dit was veral deur Athanasius se invloed dat in die Geloofsbelydenis van Nicea dié gedeeltes opgeneem is wat van Jesus Christus sê: ,gebore uit die Vader vóór alle eeue (om daarmee die gebore uit die Vader én sy ewigheid te bely; waaragtige God uit waaragtige God; gebore (dus 'n ewige verhouding van liefde teenoor die Vader), nie gemaak nie (teenoor Arius se ,gemaak en geskape"), van dieselfde wese as die Vader, deur Wie alle dinge gemaak is (homoousios).$^{38}$

Athanasius ken nog nie die latere onderskeidenheid wat deur die woord persona uitgedruk is nie. Om hierdie onderskeidenheid uit te druk (en sodoende nie in "Sabellianisme" te verval nie), sê hy dat die Vader en die Seun in alles gelyke is (in ewigheid, mag, heerskap, eer, wese, goddelikheid), behalwe dat die Vader nie die Seun is nie en die Seun nie die Vader nie. In plaas van „die persoon van die Vader of Seun", sê hy net Vader en Seun, en i.p.v. twee Persone, sê hy net „Twee"..39

Dat die Seun gebore is (gennétos), dat die Vader Hom verwek het wil dus vir Athanasius geensins sê dat die Seun geword het (genétos), dat Hy 'n begin gehad het, en dat Hy nie in alle opsigte aan God gelyk is nie (behalwe natuurlik dat Hy Seun is en nie Vader nie). Deur die feit dat die Vader die Seun verwek het is daar 'n ordo, nl. dat die Wese van die Vader die oorsprong en bron van die Seun is. Hierdie ordo tas nie die wesenlike eenheid van die Seun met die Vader aan nie, en doen ook niks aan sy Goddelikheid af nie. En tog stel hierdie ordo twee dinge, nl.:

a) Dit onderskei die Persoon van die Seun van Dié van die Vader; en

b) Dat die ousia (wese) van die Vader die oorsprong, wortel en bron van die Seun is, word gestel teen die opvatting as sou daar 'n afsonderlike ousia (wese) wees waaruit beide (Vader en Seun) is. 
Deur die segswyse van Athanasius word aangetoon dat daar nie vier Gode is, nl. 'n afsonderlike Ousia (wese), 'n Vader, 'n Seun en 'n Heilige Gees is nie, maar dat aldrie dieselfde Wese (ousia) ten volle het en nie 'n deel van die Wese nie.

Deur dus te sê dat die Seun voor alle eeue uit die Vader gebore is, word die Seun se ewigheid bewaar; deur te sê dat die Seun voor alle eeue uit die Vader gebore is, word die eenheid van God bewaar.40 Die leer van Arius word subordinasie genoem - die Seun is gesubordineer, ondergeskik aan die Vader. Die leer van Athanasius word ontologies genoem - van dieselfde Wese as die Vader.

Volgens die leer van die subordinasie, en dat Christus 'n laere of mindere God is, is ons heil onseker. As Jesus Christus alles maar net van die Vader ontvang het (Arius), dan kon Hy miskien Homself red maar nie ander nie. ${ }^{41}$ Daarom is Jesus Christus nie 'n wese tussen die geskape en ongeskapene nie, maar is Hy ten volle God wat ten volle mens geword het, wat 'n geskape menslike natuur aangeneem het sonder dat daar verandering van òf sy volle Godheid of sy volle mensheid was, of sonder dat beide vermeng is. ${ }^{42}$

Daarom is die Seun se eenheid met die Vader wesenseenheid en nie bloot wilseenheid. Hierin lè die sleutel vir die hele stryd rondom die Triniteit.

Elkeen wat sê dat die Vader die Seun uit sy wil voortgebring het, sonder om te sê dat sy wil liefde, d.w.s. Wese is, bring die Seun af. In hierdie opsig voel Athanasius saam met Alexander wat teenoor Arius sê: „Arius-hulle laat dié Skrifstukke weg wat oor die Godheid van die Seun handel. Op hierdie wyse kom hulle tot die goddelose konklusie dat Paulus en Petrus dieselfde as Christus sou gewees het, as hulle maar net altyd in die goeie weg sou gebly het".48 Daarom stel hulle teenoor Arius dat Jesus Christus nie sy Godheid uit die wil van die Vader ontvang as beloning vir sy voortdurende sedelike gehoorsaamheid nie, maar dat Jesus Christus wesenlik, ewige en waaragtige God is.

Dit is hierdie Christologie van Athanasius c.s. wat die geloofsbelydenis van Nicea gevorm en beheers het. Alles hang hiervan af: indien Jesus Christus 'n laere of mindere God was, dan is daar geen verlossing nie en ons heil is onseker.

Arius wou die monoteïsme beskerm deur alleen van die Vader ewige godheid te bely, maar eindig in 'n politeīsme met sy verskillende Gode, nl. Skepper God (Vader) en die Geskape God (Christus).

Athanasius het die gnostiese dualisme tussen God en wêreld verwerp wat deur Arius oorgeneem was. Die Triniteit, sê Athanasius, het niks vreemds met hom vermeng; bestaan nie uit die Skepper én iets wat geword het, maar is geheel en al volmaak Goddelik. Die Triniteit word nie, Hy is alles ewiglik. ${ }^{44}$

2. Sabellianisme (of Patripassianisme). Hierdie rigting is eksponent van die modalistiese monargisme (in vgl. met Arianisme as dinamistiese monargisme). Ons gee slegs die essensiële kern weer. Hierdie rigting beantwoord die vraag: hoe God in die vlees verskyn het?, soos volg: 
Jesus Christus word, op grond van Athanasius se Skrifgedeeltes, erken en bely as ewige, waaragtige, wesenlike God met al die kwaliteite wat by die waaragtige divinitas (godheid) pas, soos bv. ewige majesteit, eer, heerskap, ens.

Waar Arius leer dat Jesus ten volle waaragtig mens was, maar nie ook ewig God nie, leer die Sabellianisme dat Jesus ten volle waaragtig God was, maar dat $\mathrm{Hy}$ nie ten volle 'n menslike natuur aangeneem het nie. Sy menslikheid word dan gesien as 'n tydelike verskyningsvorm.45 Volgens hierdie leer is die Griekse term vir persoon, nl. prosópon alleen 'n tydelike masker. Dit dui geen werklike persoonlike onderskeid aan nie en daar is geen permanente onderskeid tussen die sogenaamde drie Persone nie. God is in strengste $\sin$ Een; die sogenaamde Persoonsonderskeid is alleen maar die opsit van verskillende maskers, prosopa. Toe God mens geword het, het Hy net die masker van die menslike vlees (sartes) tydelik opgesit en dit weer laat vaar na sy menswording.

In hierdie rigting sit 'n sterk docetiese trek, nl. dat Jesus Christus nie werklik, wesenlik, substansieel mens geword het nie, maar alleen skynbaar (dokein = skyn).

Ons vind hierdie docetiese trekke vandag nog, nie net i.v.m. die menslike gestalte (natuur) van Jesus Christus nie; maar ook i.v.m. die "menslike gestalte" van die Heilige Skrif.4 Ook hierdie rigting neem die heilssekerheid weg omdat dit die realiteit van die vleeswording ontken. Die vleeswording is net 'n drama (waarvan die verskillende Persone maskers (prosopa) is), 'n spel, maar dit het nie werklik gebeur nie. ${ }^{4 \gamma}$ Daarmee verval die sekerheid wat spruit uit die plaasvervangende lyding van Jesus Christus, dat Hy soos een van ons geword het en werklik vir ons in ons plek gely, gesterf en opgestaan het.

3. Eutyches ${ }^{48}$ (Monofisitisme). 'n Derde rigting om die verhouding tussen die Vader en die Seun vas te stel en die geheim van die vleeswording onder woorde te bring, is die van Eutyches: God se Gees (dikwels God Self) het in ons liggaam ingedaal en so het 'n nuwe godmenslike wese ontstaan waarin ongeskapenheid en geskapenheid, Goddelikheid en menslikheid vermeng, saamgesmelt het; die menslike is deur die Godheid geabsorbeer.

Die heilssekerheid verval ook hier, want Jesus Christus se „Persoon" kom glad nie wesenlik ooreen ò met God of met die mens nie. Die beswaar teen die Arianisme, nl. dat Jesus nie werklik God geopenbaar in die vlees is nie, en dat ons verlossing en heilssekerheid dus verval, geld ook hier.

Maar ook die beswaar teen die Sabellianisme is hier ook van krag, nl. dat dit nie God geopenbaar in ons vlees, is nie. Dus word ons heilssekerheid ook op hierdie wyse ondergrawe, want dit was geen waaragtige, regverdige mens wat vir ons gely, gesterf en opgestaan het nie. Ons het nie werklik óns vlees as pand in die hemel ná sy hemelvaart nie. ${ }^{49}$ Die leer van Eutyches word monofisitisme genoem (een natuur). 


\section{Die Athanasium}

In hierdie belydenisskrif wat as geloofsbelydenis en geloofsreël van die kerk in 451 aanvaar is op die Konsilie van Chalcedon, klink die invloede van die neerslag van stryd gedurende die vorige eeue. Behalwe die stryd tussen Arius en Athanasius is hierin ook spore van Tetullianus, die drie Kappadociërs en Augustinus. Hierdie manne het die leer oor die Triniteit uitgewerk en voltooi. ${ }^{50}$

\section{Iets kortliks oor elkeen:}

Tertullianus: Die betekenis van Tertullianus is daarin dat hy die terme van die latere ortodokse Christologie gemunt het. By hom kry ons alreeds die formule: Una substantia, tres personae. Die verbinding van die drie Persone in die éen substansie beredeneer Tertullianus as volg: omdat daar drie Persone is, moet daar 'n ordo wees, nl. nommer Een, nommer Twee en nommer Drie; maar dit beteken nie dat nommer Een hoër of groter is as nommer Twee of Drie nie. Maar om nie fiktiewe Persone te wees nie, moet elkeen sy eie Persoonlikheid besit, d.w.s. sy vaste plek in die nommers Een, Twee en Drie. Al wat die ordo wil sê, is dat Persoon nommer Een, nie Persoon nommer Twee of Drie is nie, ens. Op hierdie wyse verseker Tertullianus dat daar werklik drie Persone is en dat hulle nie vermeng word nie. ${ }^{\text {s1 }}$

Hoewel Tertullianus meer as 'n eeu voor Nicea 325 (waarvandaan die Geloofsbelydenis van Nicea afkomstig is) gelewe het, is sy Triniteitsleer om drie redes belangrik:

(i) Omdat sy leer, saam met die van die Kappadociërs vir eeue die Triniteitsleer van die Weste beheers het en ook die Christologie van die Niceense en Athanasiaanse Geloofsbelydenisse gevorm het. $^{52}$

(ii) Omdat hy ook deur Calvyn aangehaal word en Calvyn belangrike terme en figure van hom gebruik, terwyl Calvyn weer op indirekte wyse die formateur van die Christologie van die Nedl. Geloofsbelydenis en van die Heidelbergse Kategismus is. ${ }^{52}$

(iii) Omdat hy die ontologiese Triniteit vir goed van die kosmologiese spekulasie losgemaak het. Hy was die eerste om die triniteit van die persone af te lei nie uit die persoon van die Vader nie, maar uit die wese van God. ${ }^{33}$

Die Kappadociërs. Die Kappadociërs is belangrik omdat: ${ }^{54}$

(i) by hulle die leer aangaande die Persoon van die Heilige Gees eksplisiet ingesluit is; en

(ii) omdat sekere terme en hulle inhoud ook weer by Calvyn, Beza, de Bres en die Nedl. Geloofsbelydenis voorkom.

In hulle Triniteitleer sê die Kappadociërs dat die Koinon (gemeenskaplike) is die Wese, en die idion (eiendomlike) is die Persone. In die Drie-enige God is daar dus nie 'n teenstelling tussen eenheid en veelheid nie, maar ' $n$ betrekking tussen die Koinon (gemeenskaplike wese) en die idion (persoonlike eienaardigheid). ${ }^{65}$ Op hierdie wyse wil die Kappadociërs uitdrukking gee an die uniekheid van 
die God van die openbaring van die O.T. en N.T. teenoor die starre Godsopvatting van die Jodendom en die veelgodendom van die heidendom. Hulle druk dit soos volg uit: „Die Eenheid in die Drieheid en die Drie-heid in die Eenheid". ${ }^{\circ 6}$ (Vgl. art. 3 van die Geloofsbelydenis van Athanasius).

Augustinus $^{57}$ het aan die Westerse beskouing oor die Triniteit in sy „De Trinitate” finale beslag gegee. Die grondslag van Augustinus se teologie was: die Eenheid van God is 'n Triniteit. Die eintlike probleem vir Augustinus was dat daar drie Persone in die Eenheid is. Augustinus sê: ,ons sê drie Persone, nie om dit uit te druk nie, maar om nie stil te wees nie”. „Drie maal het ek God gesê, maar ek het nie drie Gode gesê nie; want God driemaal is groter as drie Gode, omdat Vader, Seun en Heilige Gees een God is".

Augustinus se leer oor die Triniteit is in sy fundamentele aspekte beliggaam in die sg. Belydenis van Athanasius of Symbolum Quicunque. Ten onregte word die Belydenisskrif van Athanasius toegeskryf - dit adem geheel en al die gees van Augustinus. ${ }^{58}$

Voorbeelde van invloede op die Athanasium: ${ }^{60}$

(i) Art. 3 ,die Eenheid in die Drieheid en die Drieheid in die Eenheid" is woordeliks net so aan die Kappadociërs ontleen.

(ii) Die „nie-vermenging van die Persone" en die „nie-deel van die substansie" herinner aan Tertullianus (art. 4).

(iii) Dat die Vader, Seun en Heilige Gees elk 'n Ander (Persoon), (art. 5), is gaan terug op Athanasius.

(iv) Die eenheid van Godheid, gelyke eer en mede-majesteit (art. 6) is gebasseer op Alexander.

(v) Die ongeskape (art. 8) impliseer weer die stryd van Athanasius teen Arius.

Hierdie is maar ' $n$ fragmentariese heenwysing. Eintlik moet dit gesien en geïnterpreteer word teen die hele voorafgaande agtergrond en stryd van ruim vier eeue.

\section{Historiese verloop van die stryd ${ }^{00}$}

Hier stel ons kernagtig net die hoofbakens:

1. 325 - Konsilie van Nicea: Reeds in 320 of 321 het Alexander van Alexandrië twee kerklike vergaderings in Egipte belê. Op beide vergaderings is Arius veroordeel.

Keiser Konstantyn tree toe tot die geskil. Sy uitgangspunt is eenheid in sy ryk. Ter wille hiervan roep hy die Konsilie van Nicea byeen. Ongeveer 300 biskoppe was teenwoordig, hoofsaaklik uit die Oosterse dele. Rome is verteenwoordig deur twee presbiters. Daar was in die debat hoofsaaklik drie groepe:

a) 'n Ariaanse party, aangevoer deur Eusebius van Nicomedia, medestudent van Arius by die eksegete skool van Lucianus, en volgeling van Paulus van Samosata. 
b) 'n Kompromie-party op voetspoor van Origines. Leier: Eusebius van Cesarea. Hierdie party vermy die woord homo-ousios (eenswesens).

c) Alexander en Athanasius - die homo-ousiane.

Op die besluit van Nicea ten gunste van homo-ousios (eenswesens met die Vader) wat met 'n geringe meerderheid aanvaar is, het konflik op konflik gevolg. Athanasius moes bv. vyf maal vlug na uitsprake van konsilies - gewoonlik verban in ballingskap. 'n Ander rigting ontstaan, nl. die Semi-Ariane of die Homoi-ouriane. Dit kry beslag op die Konsilie van Antiochië - 358 .

2. 381 - Konsilie van Konstantinopel. Die invloed van die Kappadociërs, veral Gregorius van Naziansus, was sterk. Die Nicea-besluit word die "sjibbolet" en homo-ousios (eenswesens) word aanvaar. Arianisme delf nou die onderspit.

3. 451 - Konsilie van Chaleidon. Die Niceense-Konstantinopelse Geloofsbelydenis as grondslag met die gees en formuleringe van Augustinus het sy neerslag gevind op die Konsilie van Chalcedon in die Athanasium of Syntotum Quicunque.

4. 589 - Sinode van Toledo. Uitspraak word gegee oor die verhouding van die Heilige Gees tot die Vader en die Seun in die sg. formulering ,filioque". Die Heilige Gees is uitgaande, nie alleen van die Vader, maar ook van die Seun. Waar die stryd t.o.v. die Seun uitsluitlik gegaan het oor sy godheid of mensheid - sy persoonlikheid is algemeen aanvaar - was die stryd t.o.v. die Heilige Gees veral oor sy persoonlikheid.

Die Pneumatomachiërs (machomai = slegpraat) sê dat nêrens is sprake van die aanbidding van die Heilige Gees, en dat Hy telkens voorgestel word as 'n gawe en 'n $\mathrm{krag}$ (vgl. Jehowa-getuies) terwyl die enkele plekke waar van Hom as Persoon gespreek word, moet dit as personifikasie gesien word. ${ }^{01}$

Die loëning van die persoonlike bestaan en die goddelike natuur van die Heilige Gees, kom altyd bewus of onbewus voort uit 'n rasionalistiese, pelagiaanse deistiese prinsipe. Dit hoort tuis in die kring van die Ariane, Sociane, Remonstrante.

Alhoewel die kerkvaders die belydenis oor die Heilige Gees nie baie duidelik formuleer het nie, was die geloof in die Godheid en persoonlikheid van die Heilige Gees van die begin af aanvaar.

Die Oosterse kerke het nie die "filioque" van Toledo aanvaar nie, omdat uitgegaan is van subordinasie van die Heilige Gees aan die Seun (Arianisme).

Die twintigste eeu en die leer oor die Drie-eenheid. Chalcedon (451) en Toledo (589) was nie die einde van die stryd rondom die leer oor die Triniteit nie. Steeds probeer die leuen op dié of daardie wyse binnesluip. In die tyd van die Reformasie herinner ons net aan Gentilis, Servet, ${ }^{, 2}$ die Sociniane ${ }^{03}$ en die Anabaptiste. In die $19 e$ eeu moet genoem word die modernisme wat sterk laat dink aan Paulus van Samosata. ${ }^{64} \mathrm{Vgl}$. voetnoot 32 . 
In die 20e eeu skryf prof. Heering, een van die vooraanstaande regsmodernes in Nederland dat die waarheidselement in die leer van die Drie-eenheid nie te misken is nie, maar beter tot uitdrukking kom in die openbaringstriniteit: God, geopenbaar as Vader, in die Seun, deur die Heilige Gees. Die aanvaarding van die Wesenstriniteit lei syns insiens tot driegodendom. ${ }^{\circ 5}$ Hierin is verborge Sabellianisme.

Volgelinge van Arius in die 20e eeu is die Jehowa-getuies. Arius word deur hulle as die grootste deur God gegewe profete vereer.0 Wel sê hulle dat Jesus Leidsman is (Voorbeeld), ${ }^{07}$ maar dat Hy God is, ag hulle 'n versinsel van die kerk. Tot stawing van hulle opinie beroep hulle hul op Kol. $1: 15$.

Op die teologiese podium van die $20 \mathrm{e}$ eeu is Arius en Sabellius weer aan die woord in die Teologie van die Rewolusie. ${ }^{88}$ Hierdie teologie kan alleen verstaan word vanuit sy godsbegrip. ${ }^{68}$

Die godsbeeld van die teologie van die rewolusie. ${ }^{70} \mathrm{E}$. Bloch mak veral beswaar teen 'n statiese godsbeeld. Die God wat Bloch teken is 'n dinamiese God. Ons kry by Bloch selfs die motief van die wordende God - 'n evolusionistiese godsbesef. In God self is daar ontwikkeling, aksie, beweging, omwenteling, groei en verandering. Bloch gee die rewolusie en rebellie 'n legitieme plek in sy godsbegrip. God is nog nie voltooi nie.

As dit so is dan is die Drie-enige God nie ewig nie; dan word die Drie-eenheid voltrek deur die eeue langs die proses van evolusie. Arius met sy dinamiese monargisme herleef in Bloch se dinamiese godsbeeld. Hieroor het Athanasius in die $4 \mathrm{e}$ eeu al die vraag gevra: ,as die Drie-eenheid dan in die tyd ontwikkel, watter versekering het ons dat daar nie nog 'n Vierde sal bykom nie?"

Bloch is beïnvloed deur Hegel van wie hy oorgeneem het die gedagte van die teenstelling, die diskrepansie tussen die wese van die dinge en hulle verskyning. Omdat God nie voltooi is nie is daar ook nie 'n status quo in God nie. God is 'n wordende God.

Hierdie siening word vervolgens op Christus en die mens geprojekteer. Christus is ook die rewolusionêre Jesus en sy volgelinge is die rewolusionêre mens wat ook nie met die status quo tevrede mag wees nie.

Met wat hierbo gesê is in gedagte, kan ons verstaan waarom $H$. Berkhof wat vroeër redelik gereformeerd was nou meer neig na die teologie van die rewolusie. Dit hang saam met sy godsbegrip. In sy boek: De leer van die Heilige Geest (1964) het Berkhof al gepleit vir 'n dinamiese leer van die Heilige Gees. Gees beteken: God wat handel, wat optree, wat besig is in die geskiedenis. Berkhof se dinamiese beskouing oor die Heilige Gees gaan ten koste van die selfstandigheid van die werk van die Heilige Gees. Berkhof neig ook tot die gedagte dat daar in God self 'n ontwikkeling plaasvind. God word betrek in die geskiedenis van sy skepsel en wel op so 'n wyse dat Hy nie meer onafhanklik en vry daarteenoor staan nie. (Vgl. hierteenoor J. A. Heyns: Die grondstruktuur van die modalistiese triniteitsbeskouing).

In sy jongste artikel in die Tijdschrift voor Theologie (r.k.) kies 
Berkhof vir die adoptiaanse christologie en laat vaar hy die godheid van Christus (sic Arius!). Die Triniteit is vir hom: die voltooiing van God se geskiedenis met die mensheid.11 Ons kry hier 'n volkome historiese teologie. God self deurloop 'n geskiedenis.

So herleef die $4 \mathrm{e}$ eeu in die 20e eeu. Behalwe Arius, ook Marcellus van Ancyra (oorlede \pm 374 ) en Photinus van Sirmium. Hy gaan uit van die gedagte dat daar by God twee fundamentele eienskappe aanwesig is, nl. die van uitbreiding en inkrimping. ${ }^{72}$ Marcellus sê dan dat God by die skepping van die wêreld uit 'n toestand van rus oorgaan in 'n toestand van aktiwiteit. Marcellus het gekom tot 'n ontwerp van God se trinitariese uitbreiding in die geskiedenis.

Die kerkvader Eusebius het Marcellus as 'n Sabelliaan beskou. Dieselfde tendens van Arianisme en Sabellianisme sien ons ook in die nuwere teologie. God en sy skepping word korrelate begrippe. God kan nie meer los gedink word van sy skepping nie. Daar is evolusie in God soos daar ook evolusie in die skepping is. By 'n evolusionistiese siening op die skepping pas 'n Homself evoluerende God.

Die dwaalleer van die vierde eeu, Arianisme en Sabellianisme, herleef in die twintigste eeu, soms net in 'n ander gewaad!

(Gelewer voor G.T.V. Pretoria, 24 April 1972).

P. W. Bingle.

1 H. A. L. van der Linden: Het wezen Gods. In: Het dogma der Kerk, p. 112.

2 Calvyn: Institusie I, 13, 3.

3. Ibid., I, 13, 21.

4 Luther: Werke (Erlanger Ausgabe). Vol. XV, p. 57. Aangehaal deur Engelbrecht, B. J.: Enkele Dogmatiese Opmerkings oor die Kerklike leer aangaande die Triniteit, met besondere verwysing na die Status van die Pre- en Port-eksistente Christus t.o.v. die Vader. In: Hervormde Teologiese Studies; Jrg. 19, afl. III. en IV., Januarie 1964.

5 Harnack, A. von: Lehrbuch der Dogmengeschichte, 5 Auflage, Band II, pp. 204, 206. Aangehaal deur Engelbrecht, B. J.: a.w.

6 Calvyn: Inst. I, 13, 5.

7 Engelbrecht, B. J.: a.w., p. 140 verwys na A. van Selms: Lig uit Lig, Pretoria 1952, p. 136.

8 Gentiles was nie in die eintlike sin van die woord anti-trinitariër en Ariaan nie. Hy het (soos baie mense in die tyd van die Kerkhervorming) beswaar gehad teen die terme Triniteit, Wese, Persoon, Relasie, Eienskap e.s.m., omdat die terme nie in die Bybel voorkom nie. Gentilis se bedoeling was om die eenvoudige Bybelse gegewens sonder papistiese en skolastiesfilosofiese onderskeidinge aan die mense deur te gee. Gentilis sê: indien jy filosofies-dogmatiese terme wat nie in die Bybel voorkom nie, gebruik, dan beland jy by 'n veelgodendom. Vgl. Engelbrecht: a.w., p. 178.

9 Calvyn: Inst. I, 13, 3.

10 Ibid, I, 13, 5.

11 Engelbrecht, B. J.: a.w., p. 141

12 Calvyn: Inst. I, 13, 5.

13 Ibid.

14 Ibid. 
15 H. A. L. van der Linden: a.w., p. 150.

16 Bavinck, H.: Geref. Dogmatick I, p. 104.

17 Ibid., II, p. 286.

18 Ibid., II, p. 298.

19 Ibid., II, p. 301.

20 De Vries, G. J.: Plato. In: Christelike Ensiklopedie, V.

21 Bavinck: a.w. II, p. 230-233.

22 Ibid., I, p. 97.

23 Conzelman, H.: An outline of the theology of the New Testament (vertaling van: Grundriss der Teologie des Neuen Testaments, 1968) sê die Gnostiek „is a tremendous pot-pourri of Iranian, Babylonian and Egyptian ideas", p. 11.

24 Christus kry slegs die betekenis van 'n kosmiese gestalte wat in hierdie wêreld neergedaal het om die stryd aan te bind teen die duistere magte.

25 Bousset, Reitzenstein (van die 19e eeu) en Bultmann c.s. vind in die Gnostiek verklaringsbeginsels vir die leer oor gees-vleis by Paulus. Reitzenstein beskou Paulus nie as die eerste, maar as die grootste gnostikus. R. Reitzenstein: Dic hellenistischen Mysterienreligionen, 1920, p. 65; aangehaal in: Ridderbos, H.: Paulus, ontwerp van zijn theologie, Kok Kampen 1966, p. 21. Hierdie beskouing dat Paulus beïnloed is en afhanklik is van die Gnostiek is ' $n$ hipotese. Daar is geen bewys voor. Geen enkele dokument wat gevind is met die opgrawinge by Nag-Hammodi kan dateer word voor die tyd van die N.T. nie. Vgl. Van Unnik, W. C.: Openbaringen uit Egyptisch zand. Die vondste by Nag-Hammodi. In: reeks Exegetica, 1958.

26 Bavinck, H.: Geref. Dogmatiek I, p. 96.

27 Ibid., p. 102.

28 Die leemte in die Triniteitsleer van J. Martyr, kom ook voor by die ander apologete - Teofitus, Tatianus, e.a.

29 Engelbrecht, B. J.: a.w., p. 155.

30 Ibid.

31 Calvyn: Inst. I, 13, 5.

32 Schleiermacher sê Jesus was 'n besondere mens. Kant: Jesus is 'n abstrakte ideaal van etiese volmaaktheid; Hegel: God bring Homself denkende voort (Bavink: a.w., II, p. 261); Kenosis-teorie - Thomasius, Gess, Ebrard, Martensen, Geyser); Ritsch: Christus is 'n gewone mens, maar in die lig van sy werk ken ons Hom godheid toe. Ritschl is 'n moderne Paulus van Samosata - Berkhof, H.: History of Doctrines. Die moderne teologie sê Christus verskil van ander mense alleen daarin dat $\mathrm{Hy}$ meer bewus was van God se inwoning in Hom. Hierin is ooreenkoms met Theodor Mopsuestia wat geen essensiêle verskil, alleen verskil in graad sien tussen die inwoning van God in Christus en in die gelowiges.

33 Engelbrecht, B. J.: a.w., p. 155.

34 Vir die volgende uiteensetting van Arius sien Harnack II, pp. 190-204 en Bethune-Baker, J. F.: An introduction to the early History of Christian Doctrine, London 1958; pp. 156-163. Beide werke soos aangehaal deur Engelbrecht: a.w., pp. 156 e.v.

35 Harnack II, p. 213 (noot 3) en Van Selms: Lig uit Lig, p. 56-57 en Engelbrecht: a.w., p. 159.

36 Harnack II, p. 204 (noot 1) en 205 (noot 2). In: Engelbrecht: a.w., p. 159.

37 Engelbrecht: a.w., p. 160. 
38 Ibid., p. 159.

39 Harnack II, p. 212 (noot 2) en Engelbrecht: a.w., p. 160.

40 Engelbrecht: a.w., p. 161.

41 Harnack II, p. 209 (veral nooit 1); aangehaal deur Engelbrecht: a.w., p. 161.

42 Harnack II, p. 218; Engelbrecht, p. 161.

43 Harnack II, p. 205 (noot 1) en Engelbrecht, p. 162.

44 Bavinck II, p. 252.

45 Harnack I, p. 216; Engelbrecht, p. 163.

46 Engelbrecht, p. 163.

47 Harnack I, p. 759 en Bethune-Baker, p. 102-112. Gesiteer deur Engelbrecht: a.w., p. 163.

48 Eutyches was 'n kloosterowerste ( \pm 378-453); aanhanger van die Alexandrynse Skool. Op die 4e Ekumeniese Konsilie van Chalcedon (451) is hy veroordeel - dit was die invloed van Pous Leo I. G. P. van Itterzon: Chr. Ensiklopedie II, p. 668.

49 Engelbrecht: a.w., pp. 163-164.

50 Bavinck: II, p. 251.

51 Engelbrecht: a.w., p. 164, 165.

52 Ibid.

53 Bavinck: II, p. 250.

54 Engelbrecht: a.w., p. 168 (voetnoot 145). Engelbrecht verskil met Harnack (II, pp. 295-296) wat sê dat daar by die Kappadociërs subordinasie van die Seun en die Heilige Gees t.o.v. die Vader is. Engelbrecht toon aan uit die oorspronklike o.a. Basilius se „Tractatus de Spir Sanet” dat daar geen grond vir Harnack se subordinasiaanse opvatting is nie.

Harnack: II, p. 265 (noot); Engelbrecht: a.w., p. 169.

56 Engelbrecht: a.w., p. 169.

57 Aantekeninge oor Augustinus uit: Seeberg, R.: The history of doctrines.

58 Bavinck: a.w., II, p. 254.

59 Engelbrecht: a.w., pp. 172, 173.

60 Vir die historiese oorsig is hoofsaaklik gebruik gemaak van $R$. Seeberg: The history of Dictrines; L. Berkhof: The history of Christian Doctrines; J. N. D. Kelly: Early Christian Doctrines.

61 Bavinck: a.w., II, p. 277.

62 Servet noem die Triniteitsleer 'n driekoppige Cerebus, 'n Gregoriese monster ('n mitiese koning op die eiland Erythrea met drie liggame). Hy noem die „ewige generasie" 'n sotheid. Vgl. Engelbrecht: a.w., p. 179.

63 Die Sociniane sê God is een in Wese en een in Persoon - verborge Sabellianisme.

64 Van der Linden: a.w., p. 159.

65 Ibid.

66 Ibid.

67 Christus as Voorbeeld word afgelei uit Arius se leer dat die Seun in 'n wilseenheid staan met die Vader (en nie wesenseen). Arius herleef!

68 Harvey Cox, Richard Shaull en Jurgen Moltmann spreek van 'n teologie van die rewolusie. Hulle staan almal onder invloed van die neo-marksistiese Joodse filosoof Ernst Bloch. Bloch self is weer beïnvloed deur Thomas Münzer oor wie hy 'n boek geskryf het. In Nederland staan H. M. Kuitert weer duidelik onder invloed van J. Moltmann.

69 Literatuur oor die Teologie van die Rewolusie: E. Bloch: Thomas Munzer 
als Theologe der Revolution, Berlin 1921. E. Bloch: Das Prinzip Hoffnung, Suhrkamp Verlag 1959. R. Shaull: Die Kirche und die Revolution, in: Evang. Theologie, 1967, pp. 646-663. J. Moltmann: God in de revolutie, in: Wending, Maart 1969. H. Berkhof: De leer van die Heilige Geest, 1964. E. Lohse: Epochen der Dogmeugeschichte.

70 Vir die gedagtes oor die teologie van die revolusie is hoofsaaklik gebruik gemaak van aantekeninge van prof. $d r$. L. Floor; ongepubliseerd 4-3-1972.

71 Dieselfde opvatting word gevind by G. A. F. Knight in sy studie: A Biblical approach to the Doctrine of Trinity, in: Scottisch Journal of Theology, Occasional Papers, no. I2, Edinburgh, 1957.

72 Bavinck: a.w., II, p. 259. 